\section{ETPC 16,3}

\section{6}

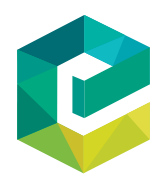

English Teaching: Practice \& Critique

Vol. 16 No. 3, 2017 pp. $286-289$

(C) Emerald Publishing Limited 1175-8708

DOI 10.1108/ETPC-10-2017-0141

\section{Introduction}

\section{Editors' introduction to the special issue on teaching politics}

When we issued the Call for Papers for this special issue on "Teaching Politics", we were motivated in part by the results of the 2016 US presidential election and its potential effects on educational equity and social justice in the country where we reside, the USA. We were also motivated by transnational discussions about refugees, nationalism, various forms of persecution, global alliances and our basic responsibility for the well-being of other humans. Despite our deep dismay at the election of a president who devalued public education, had ties to White Supremacist groups, bragged about sexually assaulting women, rejected religious tolerance and dismissed facts and science, we could not have predicted what would transpire in the USA during the six months between our Call for Papers and the publication of this issue, as rights and protections for people of color, children, women and immigrants have eroded and violence against these groups have increased. In short, it seems even more urgent to us now, both in the USA and globally, that English educators talk about politics, power, critical literacy and civic engagement in literacy instruction.

In recent years, the issue of politics has become more central in literacy research. Teachers and researchers have become increasingly aware that literacies are political and ideological and that texts cannot be taught in non-political, non-ideological ways. At the same time, such teaching had become risker in many contexts, as teachers face mounting pressure from administrators, students, parents and sometimes peers to de-politicize their teaching and to avoid controversial social issues. In the wake of racially and ethnically motivated violence and displacements, misleading information (often circulated through social media) that contradicts scientific data and knowledge on issues such as climate change, the creation of politically motivated "professor watchlists", and discussions about religious tolerance worldwide, politics have become both more integrated and central and also more contentious and divisive in ELA classrooms. How do literacy researchers and teachers navigate this tension?

In response to our call, we received an overwhelming number of thought-provoking manuscripts addressing this question. Thus, in addition to the nine articles appearing in this special issue, our first issue of 2018 will serve as a Volume 2 of the special issue on teaching politics. The nine articles in this issue, Volume 1, address issues related to teaching political texts, teaching about politics through English Language Arts and the politics of literacy teaching. Several of the articles describe how English educators bring reading, writing and talk about current political issues into their literacy classrooms and how students engage and respond in both personal and analytical ways (Hsieh; Muhammad, Mason-Chisholm and Starks; and Torres and Tayne). Taken together, these studies suggest that the inclusion of current political issues in literacy education provides engaging, meaningful and rigorous literacy learning opportunities to students of all ages. Other articles (Davila and Barnes; Smagorinsky et al:; Kinloch and Dixon) describe how teacher educators prepare new teachers to navigate issues of politics, diversity and racism through their teaching practices. A third set of studies (Metz; Schmidt, Jacobs and Meyer; Hungerford-Kresser and Vetter) investigate how teachers resist or appropriate broader sociopolitical discourses related to language ideologies, literacy assessment and standards for learning. Though the research and educator narratives represented in this issue range in topics and settings, one overarching theme emerges: literacy instruction is inherently political, and to suggest otherwise is to ignore a large body of evidence showing the ways in which broader political 
debates and policies concerning education, human rights and social justice shape educators' everyday practices.

Hsieh's teacher narrative, "Making room for discomfort: exploring critical literacy and practice in a teacher education classroom", provides a powerful look into how the results of the 2016 US presidential election prompted her to rethink the power of critical literacy, both as an essential element of her literacy education course and as a means of reflecting on her own pedagogical practices. Detailing her pedagogical decision-making in the days immediately before and after the election, she discusses the central role critical literacy played in providing a space for students to share their responses to the election. At the same time, she discovers that critical literacy practices are most valuable when they help students explore a wide array of perspectives on politics - even those that seem unexpected or unanticipated.

In their study, "Beyond censorship: politics, teens, and ELA teacher candidates", Davila and Barnes examine how pre-service English language arts teachers in a teaching education program in the Southern USA think about politics. Specifically, they investigate how these teacher candidates position political texts, how they interpret the political views of young people and how they view the prospect of engaging in political discussion in their future classrooms. The authors find that many of these pre-service teachers would choose to avoid any discussion of politics over risking judgment or criticism. In light of these findings, the authors articulate concerns about how such political silence denies young people access to multidimensional conversations about texts and politics.

Smagorinsky, Brasley, Johnson and Shurtz's educator narrative, "A letter to teacher candidates at the dawn of the Trump Presidency", provides another perspective on teacher education in the Southern USA in the wake of Donald Trump's election to the US Presidency. Smagorinsky describes the letter he wrote to the students at the beginning of his education service-learning course, explaining how it aimed to foster teacher candidates' appreciation of diverse people and students at a time when political rhetoric and policy emphasized a distain for such tolerance. Smagorinsky explains his reasoning for sharing his own political views, values and neuroatypicalities with his students and handing over curricular decision-making and interpretive authority to students to reframe power and "political correctness" in education as mutual respect and acknowledgement of unfamiliar perspectives. Co-authors Brasley, Johnson and Shurtz, students in the class, describe their responses to Smagorinsky's letter and the ways it shaped their learning experiences. Their narrative makes the case that being transparent about one's politics and values does not necessarily create a biased or ideological learning environment and can instead foster meaningful and honest discussions of multiple perspectives.

Kinloch and Dixon's study, "Equity and justice for all: the politics of cultivating antiracist practices in urban teacher education”, examines the politics of cultivating anti-racist practices with pre- and in-service teachers in the USA. The study delves into key question about how teacher educators and pre- and in-service teachers navigate the politics of teaching through anti-racist practices, finding that creating spaces in which teacher can "story" feelings of marginalization is central to creating and enacting liberatory forms of teacher education - especially in urban context.

"Exploring \#BlackLivesMatter and sociopolitical relationships through kinship writing" by Muhammad, Mason-Chisholm and Starks describes their study of adolescent Black youths' "kinship poetry" on sociopolitical issues related to racism and marginalization. Drawing from the cultural history of kinship writing among Black American authors - the tradition of writing in in response to sociopolitical issues raised 
ETPC

16,3

288

in a previous piece of writing - Muhammad and her co-authors designed and studied a summer writing program grounded in Black Studies. They first describe the themes that appeared most often in the youths' poetry, including the need for racial equality, the neglect and omission of Black lives and the suppression of freedom. They then, through text analysis and interviews, analyze how the youth authors took up stylistic and rhetorical features of the original texts as they became inspired to convey their lived experiences to new audiences. Their article raises important implications for teaching about social justice, agency, audience and purpose through writing, particularly for youth of color whose lived experiences with racism and oppression rarely are given space in the English curriculum.

In his essay, "Addressing English teachers' concerns about decentering Standard English”, Metz discusses the heightened social and political meaning that the teaching of grammar and usage takes on in our current political context. Providing a valuable synthesis of recent scholarship on teaching grammar, usage and language variation, Metz reflects on his own experiences to provide fresh insights into the relationship between language, culture, and power in the English classroom. Ultimately, he makes the case for embracing multiple Englishes and teaching English language variation by exploring the questions and concerns of teachers and administrators he has worked with over his career.

In "Super Heroes, villains, and politics: Elementary youth superhero narratives in an afterschool program", Torres and Tayne explore young Latinx children's responses to the 2016 US Presidential Election through students' exploration of superhero narratives in an afterschool club. Having begun an exploration of the genre with these students prior to the election, the authors found that following the election, many students were eager to create superhero counter-narratives of the election that resisted racists rhetorics and positioned the President-Elect through conventions related to prototypical villains. At the same time, the authors found that conventions and norms related to heroes' interaction with villains helped students discover positive and generative reactions to the election as well as narratives of hope.

In "Sociopolitical Testing Discourses in Elementary Teachers' Talk About Reading Assessment", Schmidt, Jacobs and Meyer, the authors investigate how sociopolitical discourses surrounding a mandated state-level reading assessment make their way into teachers' and reading specialists' talk as they discuss the merits and challenges of the assessment. Schmidt and colleagues demonstrate how politically charged rhetoric at the policy level - such as detecting student deficiencies, privileging efficiency, and reinforcing gatekeeping - makes its way into teachers' perceptions of their students, their students' families, and productive pedagogy. The authors also document the subtle expansion of such discourses from early elementary contexts, for which the reading assessments were developed, to middle and high schools, where their application is developmentally inappropriate. In conclusion, the authors suggest that elementary and secondary educators form alliances to question and resist political discourses about assessments, students, and standardization that run contrary to research on the complex, multi-faceted nature of reading and literacy learning.

The final article in this special issue, "Political tensions: English teaching, standards, and postsecondary readiness", Hungerford-Kresser and Vetter's study, takes a broad view of the politics of teaching English in the USA, examining the tension teachers experiences between teaching for college and career readiness and teaching to meet state accountability standards. Drawing on case-studies of two early-career English language arts teachers, the authors find that such tensions can be mediated by the personal 
experiences novice teachers bring into their classrooms; collaborative spaces and strategies for interrogating standards and practices; and reflective and ongoing mentorship partnerships. The authors recommend that English language arts teacher education programs should be starting places for helping novice teachers learn to navigate the competing goals that come with our increasingly high-stakes, political educational landscape.

Amanda Godley

University of Pittsburgh, Pittsburgh, Pennsylvania, USA, and

Amanda Haertling Thein

University of Iowa, Iowa City, Iowa, USA 